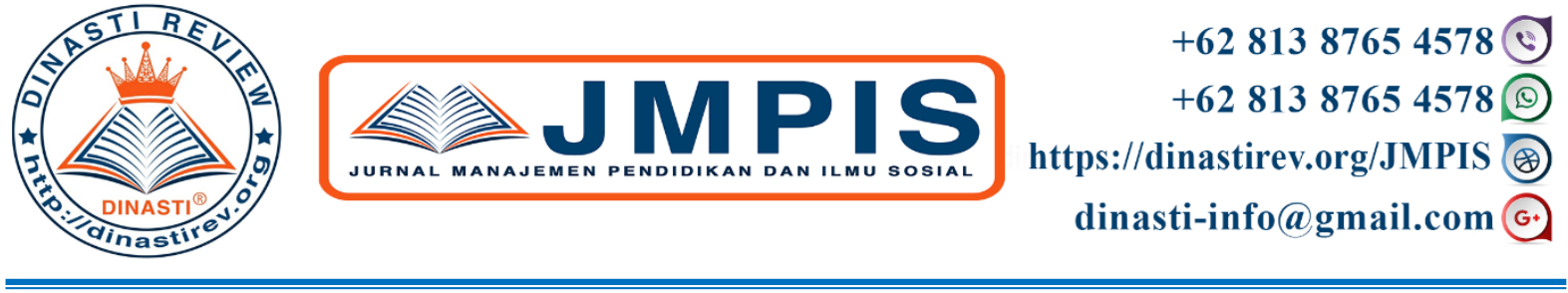

BUSINESS ETHICS PADA PT. PLN (PERSERO)

\title{
Surya Fitriadi
}

Program Pasca Sarjana, Universitas Mercubuana, Jakarta, Indonesia

\begin{tabular}{|c|c|}
\hline $\begin{array}{l}\text { ARTICLE INFORMATION } \\
\text { Received: } 9 \text { Mei } 2020 \\
\text { Revised: } 15 \text { Mei } 2020 \\
\text { Issued: } 22 \text { Mei } 2020 \\
\text { Corresponding author: } \\
\text { first author } \\
\text { E-mail: } \\
\text { surya_fitriadi@yahoo.com }\end{array}$ & $\begin{array}{l}\text { Abstrak: Sesuai Undang-undang Nomor } 30 \text { Tahun } \\
2009 \text { tentang ketenagalistrikan serta Anggaran Dasar } \\
\text { Perusahaan, secara garis besar kegiatan usaha PLN } \\
\text { meliputi : 1. Menjalankan usaha penyediaan tenaga listrik } \\
\text { yang terdiri dari pembangkitan, penyaluran, distribusi, } \\
\text { perencanaan, pengembangan dan penjualan, 2. Menjalankan } \\
\text { usaha penunjang yaitu konsultansi ketenagalistrikan, } 3 . \\
\text { Kegiatan-kegiatan lainnya antara lain pengelolaan dan } \\
\text { pemanfaatan SDA dan sumber energi lainnya, jasa operasi, } \\
\text { industri perangkat keras dan lunak dan lainnya. Sebagai } \\
\text { satu-satunya perusahaan penyedia listrik di Indonesia, } \\
\text { dengan lebih dari 53.000 jumlah pegawai, maka dalam } \\
\text { mengelola perusahaan sebesar PLN dibutuhkan suatu } \\
\text { pedoman yang mengatur cara melakukan bisnis yang } \\
\text { mencakup seluruh aspek yang berkaitan dengan individu, } \\
\text { perusahaan dan masyarakat. Pada tahun 2005, Perusahaan } \\
\text { mengeluarkan Standar Etika Perusahaan atau Pedoman } \\
\text { Perilaku/Code of Conduct (CoC) sebagai panduan bagi } \\
\text { seluruh insan PLN untuk senantiasa berperilaku profesional } \\
\text { dan menjunjung tinggi integritas di lingkungan kerjanya. } \\
\text { Pedoman perilaku ini wajib dilaksanakan oleh seluruh } \\
\text { pegawai PLN dan anak perusahaan termasuk Direksi dan } \\
\text { Dewan Komisaris, Investor, Mitra kerja, Pemerintah/DPR, } \\
\text { masyarakat, media, organisasi, profesi/instiusi pendidikan, } \\
\text { penegak hukum. Sosialisasi Pedoman Perilaku dilakukan } \\
\text { terus menerus untuk menjadikannya sebagai budaya } \\
\text { perusahaan. Budaya perusahaan akan mendorong perilaku } \\
\text { etis yang dapat menimbulkan rasa saling percaya antar PLN } \\
\text { dan Stakeholders. } \\
\text { Kata Kunci: Etika Bisnis, Pedoman Perilaku }\end{array}$ \\
\hline
\end{tabular}

\section{PENDAHULUAN}

Dalam era yang dipenuhi persaingan bisnis global yang semakin tajam, PLN perlu memiliki suatu ciri khas yang membedakan dengan perusahaan-perusahaan lainnya. Sebagai satu-satunya BUMN yang memproduksi listrik yang menguasai hajat hidup orang banyak, maka tugas utama PLN adalah : 
1. Ketersediaan listrik yang cukup

2. Distribusi listrik yang merata

3. Harga jual listrik yang terjangkau.

Sebagai perusahaan yang menguasai bisnis listrik dari hulu ke hilir yang meliputi pembangkit listrik, penyaluran transmisi, distribusi ke pelanggan dan pelayanan pelanggan, maka bisnis usaha kelistrikan membutuhkan kepercayaan yang tinggi dari Stakeholder.

Sebagai sebuah Perseroan Terbatas yang tujuannya adalah memupuk laba agar investasi kelistrikan bisa terus berjalan, PLN juga berperan sebagai agen pembangunan. Sebagai agen pembangunan maka tugas PLN termasuk melistriki suatu daerah yang tidak menguntungkan secara bisnis bahkan rugi dari sisi keuangan. Dengan tingginya target elektrifikasi nasional yang ditetapkan oleh pemerintah dan tarif listrik yang dibawah harga keekonomian, menjadi tantangan tersendiri bagi PLN.

Belanja operasi dan Investasi PLN sangat terpapar oleh kondisi pasar (market base) seperti melemahnya nilai tukar rupiah, kenaikan harga bahan bakar pembangkit listrik (energi primer) batubara, minyak bumi dan gas sementara disisi lain tarif listrik yang diatur pemerintah (regulated) tidak naik. Hal ini merupakan bentuk keberpihakan PLN pada masyarakat dan kontribusi bagi pertumbuhan ekonomi nasional.

Untuk meningkatkan kredibilitas dan membangun corporate image PLN dimata stakeholdernya, PLN harus melaksanakan bisnis sesuai dengan Standar Etika Perusahaan atau Pedoman Perilaku/Code of Conduct (CoC). COC menjadi panduan bagi seluruh insan PLN untuk senantiasa berperilaku profesional dan menjunjung tinggi integritas di lingkungan kerjanya. Pedoman Perilaku mengatur aspek kepemimpinan di Perusahaan, keanggotaan yang bertanggung jawab, hubungan profesional antar anggota dan hubungan dengan pihak eksternal. Selain itu, Pedoman Perilaku merupakan sarana untuk menciptakan hubungan yang harmonis, sinergis dan saling menguntungkan di antara seluruh pemangku kepentingan Perusahaan.

\section{KAJIAN PUSTAKA}

Menurut bahasa Yunani Kuno, etika berasal dari kata ethikos yang berarti 'timbul dari kebiasaan'. Etika adalah cabang utama filsafat yang mempelajari nilai atau kualitas yang menjadi studi mengenai standar dan penilaian moral. Etika mencakup analisis dan penerapan konsep seperti benar, salah, baik, buruk, dan tanggung jawab, Ali (2020).

Untuk mencapai tujuan bisnis jangka panjang perusahaan sesuai dengan visi dan misi yang telah ditentukan, dibutuhkan adanya Etika Bisnis. Etika bisnis dilakukan berdasarkan metoda dan cara berpikir yang sesuai logika yag ada di masyarakat. Bisnis harus dilakukan dengan tidak melanggar hak orang lain dan dilakukan dengan penuh rasa tanggungjawab. Memahami apa yang benar atau salah dan dapat diterima atau tidak dapat diterima berdasarkan harapan organisasi dan masyarakat merupakan pengertian dari Etika Bisnis, Mulyaningsih (2017).

Nilai, norma dan perilaku karyawan dan pimpinan akan terbentuk jika etika bisnis diterapkan dalam suatu perusahaan. Prinsip beretika dipastikan menjadi prinsip yang membawa kebaikan bagi perusahaan. Oleh karena itu, semua karyawan dan pimpinan diajak untuk mempedomani etika tersebut sebagai kunci dalam bekerja. 
Etika bisnis dalam perusahaan memiliki peran yang sangat penting, yaitu untuk membentuk suatu perusahaan yang kokoh dan memiliki daya saing yang tinggi serta mempunyai kemampuan menciptakan nilai (value-creation) yang tinggi, diperlukan suatu landasan yang kokoh. Biasanya dimulai dari perencanaan strategis, organisasi yang baik, sistem prosedur yang transparan didukung oleh budaya perusahaan yang andal serta etika perusahaan yang dilaksanakan secara konsisten dan konsekwen. Dengan memegang teguh etika atau moral bisnis yang ada bisnis akan berjalan dengan baik, karena dengan memiliki etika kita dapat bersaing dengan perusahaan lain tanpa merugikan pihak manapun.

Etika bisnis berbeda dari etika pribadi. nilai-nilai pribadi seperti kejujuran dan keadilan, yang penting dalam

pengambilan keputusan etis di tempat kerja, tetapi mereka hanya salah satu elemen yang memandu tindakan dan strategi organisasi. keputusan bisnis melibatkan kompleks ekonomi, hukum dan sosial. pertimbangan dan waktu bertahun-tahun pengalaman dalam industri untuk memahami risiko dan perilaku yang diharapkan, Mulyaningsih (2017).

Kunci sukses seorang pemimpin adalah kemampuan menciptakan karyawan yang mampu mengelola resiko pekerjaannya sehingga tujuan perusahaan dapat tercapai. Transformasi kepemimpinan adalah bagaimana meningkatkan kepedulian bawahan dalam pencapaian tujuan organisasi sekaligus pencapaian Visi dan Misi organisasi, Widodo (2017). Proses rekrutmen karyawan yang benar dan proses training development karyawan akan menghasilkan karyawan yang profesional. Ditambah lagi sistem karir yang jelas akan meningkatkan keterikatan pegawai (employe engagement) terhadap perusahaan.

Training menyangkut etika bisnis kepada karyawan dan pemangku kepentingan membuat etika organisasi menjadi jelas. Sumber daya manusia harus dilihat sebagai investasi karena merupakan kunci perusahaan untuk membangun kepercayaan dan hubungan jangka panjang. Pelatihan harus direncanakan oleh perusahaan untuk meningkatkan pengetahuan dan wawasan karyawan sesuai kebutuhan agar produktifitas meningkat. Kinerja pegawai yang baik merupakan investasi bagi perusahaan, karena jika budaya organisasinya bagus maka akan meningkatkan reputasi dan kepercayaan dari stakeholder dan rekan bisnis, sehingga akan berdampak pada meningkatnya keunggulan dalam persaingan bisnis. Di sekolah bisnis dan berbagai seminar, para pimpinan perusahaan diajarkan etika tingkah laku yang bertujuan meningkatkan nilai moral individu agar terhindar dari pelemahan moral dan mempunyai pemahaman yang sama, Wagner (2008).

Komunikasi secara benar dan efektif dalam suatu organisasi sangat diperlukan karena apa bila manajer atau pimpinan tidak bisa berkomunikasi secara efektif pada karyawan maka kebijakan, instruksi, visi dan misi organisasi akan sulit dimengerti oleh karyawan sehingga akan menghambat kelangsungan oprasional organisasi dan jika pegawai tidak bisa berkomunikasi dengan bebas dengan pimpinannya maka jika ada hambatan, masalah akan susah diantisipasi oleh pimpinan sehingga pimpinan akan lambat dalam mengambil tindakan dan kebijakan dalam mengatasi masalah. Sehingga komunikasi antara atasan dan bawahan secara benar dan efektif sangat diperlukan untuk kelancaran jalannya organisasi agar tujuan organisasi dapat tercapai

Prinsip-prinsip etika bisnis menurut Sonny Keraf (1998) sebagai berikut:

1. Prinsip otonomi merupakan sikap dan kemampuan yang dimiliki manusia dalam pengambilan keputusan dan melakukan tindakan berdasarkan kesadarannya terkait apa yang dianggapnya baik untuk dilakukan. 
2. Terdapat tiga lingkup batasan kegiatan bisnis pada prinsip kejujuran yang dapat ditunjukkan dengan jelas bahwa bisnis tidak akan bertahan lama dan berhasil jika tidak didasari dengan kejujuran, yaitu kejujuran dalam memenuhi setiap persyaratan dalam perjanjian dan kontrak, kejujuran pada saat memberikan penawaran barang atau jasa dengan kualitas dan harga yang sebanding, dan yang terakhir adalah kejujuran dalam hubungan kerja intern di dalam sebuah lingkungan perusahaan.

3. Prinsip keadilan mengharuskan supaya setiap personel diperlakukan secara adil sesuai dengan aturan yang berlaku secara adil dan sesuai dengan kriteria yang rasional obyektif, dan dapat dipertanggungjawabkan.

4. Prinsip saling menguntungkan (mutual benefit principle) menuntut agar bisnis dijalankan sedemikian rupa sehingga menguntungkan semua pihak.

5. Diutamakan untuk dihayati sebagai tuntutan internal dalam diri pelaku bisnis atau perusahaan pada prinsip integritas moral supaya dapat menjalankan bisnis dengan tetap menjaga nama baik pimpinan, para karyawan, ataupun perusahaannya.

Secara terperinci, Richard T.de George menyebut bahwa etika bisnis menyangkut empat kegiatan sebagai berikut:

1. penerapan prinsip-prinsip umum dalam praktik bisnis. Berdasarkan prinsi-prinsip etuka bisnis itu kita dapat menyoroti dan menilai apakah suatu keputusan atau tindakan yang diambil dalam dunia bisnis secara moral dapat dibenarkan atau tidak. Dengan demikian etik bisnis membantu pra pelaku bisnis untuk mencari cara guna mencegah tindakan yang dinilai tidak etis.

2. Etika bisnis tidak hanya menyangkut penerapan prinsip-prinsip etika pada dunia bisnis, tetapi juga metaetika. Dalam hubungan ini, etika bisnis mengkaji apakah perilaku yang dinilai etis pada individu juga dapat berlaku pada organisais atau perusahaan bisnis. Selanjutnya etika bisnis menyoroti apakah perusahaan mempunyai tanggung jawab sosial atau tidak.

3. bidang telaah etika bisnis menyangkut pandangan - pandangan mengenai bisnis. Dalam hal ini, etika bisnis mengkaji moralitas sistem ekonomi pada umumnya dan sistem ekonomi publik pada khususnya, misalnya masalah keadilan sosial, hak milik, dan persaingan.

4. Etika bisnis juga menyentuh bidang yang sangat makro, seperti operasi perusahaan multinasional, jaringan konglomerat internasional, dan lain- lain.

Tujuan etika bisnis adalah menggugah kesadaran moral para pelaku bisnis untuk menjalankan good business dan tidak melakukan monkey business atau dirty business. Etika bisnis mengajak para pelaku bisnis mewujudkan citra dan manajemen bisnis yang baik (etis) agar bisnis itu pantas dimasuki oleh semua orang yang mempercayai adanya dimensi etis dalam dunia bisnis. Hal ini sekaligus menghalau citra buruk dunia bisnis sebagai kegiatan yang kotor, licik, dan tipu muslihat, Ali (2020).

Pelanggaran etika bisa terjadi di mana saja, termasuk dalam dunia bisnis. Untuk meraih keuntungan, masih banyak perusahaan yang melakukan berbagai pelanggaran moral. Nama baik dunia bisnis dinodai oleh berbagai berbagai skandal keuangan yang mengakibatkan resesi dunia dan meruntuhkan dasar pondasi ekonomi, Floyd (2017). 


\section{METODE PENELITIAN}

Dalam penyusunan tulisan ini, metode yang digunakan penulis adalah menggunakan metode deskriptif kualitatif dengan studi literature. Informasi didapatkan dari buku, jurnal, artikel, modul perkuliahan dan internet. Disamping itu, penulisan juga dilakukan atas dasar pengamatan dan pengalaman penulis terhadap obyek penelitian, analisis data-data, interprestasi penulis, pengalaman empiris dan pengalaman langsung yang dirasakan oleh penulis selama bekerja di PLN lebih dari 27 tahun.

Metode analisis deskriptif dilakukan dengan cara mendeskripsikan fakta-fakta yang kemudian disusul dengan analisis, tidak semata-mata menguraikan, melainkan juga memberikan pemahaman dan penjelasan secukupnya.

\section{HASIL DAN PEMBAHASAN}

PLN mempunyai komitmen untuk terus melangkah maju menghadapi tantangan eksternal maupun internal. Pencapaian kinerja usaha PLN sangat dipengaruhi kondisi-kondisi seperti kemampuan keuangan, pengembangan kapasitas daya listrik, regulasi dan manajemen pemangku kepentingan, efisiensi operasi, kesiapan human capital dan organisasi, hingga masalah kualitas pelayanan dan kepercayaan pelanggan.

Seluruh insan PLN tidak saja dipacu untuk bekerja lebih keras tetapi harus lebih cerdas serta melakukan langkah-langkah yang lebih nyata agar Perusahaan tidak hanya sekedar survive, tetapi juga sustain. Setiap insan PLN harus memiliki semangat "Penting dan Genting" di semua aspek bisnis, terutama dalam rangka meningkatkan pendapatan dan menekan biaya di setiap level organisasi. Para manajer disemua tingkatan harus bekerja keras dan pantang mundur dalam menyelesaikan setiap kendala dan berbagai hambatan yang ada. Tekad sebagai pelopor pembangunan melalui infrastruktur ketenagalistrikan dengan kualitas yang baik, produksi yang cukup dan harga yang terjangkau, tentunya akan menjadi pemicu pertumbuhan ekonomi untuk meningkatkan kesejahteraan masyarakat.

\section{Pengelolaan Sumber Daya Manusia (SDM)}

Dalam mengelola SDM, PLN mengedepankan budaya sebagai peran penting guna mencapai visi, misi, dan target perusahaan. Visi PLN yaitu "Diakui sebagai perusahaan kelas dunia yang bertumbuh kembang, unggul dan terpercaya dengan bertumpu pada potensi insani.

Sedangkan Misi PLN :

1) Menjalankan bisnis kelistrikan dan bidang lain yang terkait, berorientasi pada kepuasan pelanggan, anggota perusahaan, dan pemegang saham.

2) Menjadikan tenaga listrik sebagai media untuk meningkatkan kualitas kehidupan masyarakat.

3) Mengupayakan agar tenaga listrik menjadi pendorong kegiatan ekonomi.

4) Menjalankan kegiatan usaha yang berwawasan lingkungan

Untuk mendukung program strategis, PLN terus mensosialisasikan dan menggalakkan budaya sebagai program unggulan sehingga menjadi mindset, values, dan beliefs yang menjadi standar \& identitas bagi perusahaan serta professional bagi pegawainya.

Program pengembangan SDM terdiri dari 3 bagian utama yaitu:

a. Change Agent, merupakan penunjukan pegawai PLN sebagai pelopor dan pengawal program PLN Berintegritas sekaligus sebagai kepanjangan tangan manajemen dalam 
melakukan internalisasi dan memastikan baik kebijakan maupun produk PLN tersampaikan ke seluruh pegawai yang ada di Unit kerjanya masing-masing.

b. Festival Budaya merupakan program penguatan Change Agent dengan mengangkat program budaya unit untuk menjadi program nasional yang akan menjadi sebuah identitas perusahaan yang mana fokus program budaya di tahun 2018 adalah perubahan perilaku yang berdampak kepada peningkatan engagement pegawai.

c. Engagement Survey merupakan survey yang dilakukan pihak ketiga(pihak independen) untuk mengevaluasi seluruh kegiatan Program budaya Unggul Unit yang bertujuan untuk mengetahui sejauh mana efektivitas dan implementasi program budaya Unggul tersebut di Unit.

Human capital di PLN merupakan aset penting untuk mendukung peningkatan kinerja Perusahaan secara berkesinambungan. Perkembangan teknologi dan dunia bisnis yang demikian maju mempengaruhi perkembangan industri ketenagalistrikan menjadi semakin kompleks dan semakin kompetitif.

Sebagai organisasi yang terus berkembang, jumlah pembangkit yang terus bertambah, jaringan yang lebih luas, dan jumlah pelanggan yang lebih banyak PLN membutuhkan pegawai yang siap dan mampu dikembangkan sebagai portofolio investasi organisasi. PLN telah mendata kebutuhan jumlah pegawai baru dan peningkatan kompetensi pegawai yang ada untuk mengantisipasi pengembangan fungsi-fungsi bisnis sesuai perkembangan. Selain meningkatkan kompetensi teknis pegawai untuk memenuhi kebutuhan fungsi operasional, PLN juga memiliki program pengkaderan calon-calon pemimpin Perusahaan masa depan. Untuk memastikan bahwa proses pembelajaran pegawai PLN dapat ditransformasikan menjadi kinerja unggul dan berdampak pada peningkatan kinerja korporat, Perusahaan memiliki PLN Corporate University (PLN CorpU) sebagai center of excellence. Visi PLN CorpU untuk menjadi pusat pengembangan kompetensi ketenagalistrikan setara kelas dunia mulai dijalankan melalui program strategis guna mendukung penciptaan nilai korporasi yang berkelanjutan.

Perusahaan menerapkan prinsip keterbukaan, kewajaran, kesetaraan dan adil tanpa membedakan suku, agama, ras, golongan dan gender dalam seluruh proses bisnis di lingkungan Perusahaan. Praktik anti-diskriminasi dalam pengelolaan sumber daya manusia (Human Capital) diterapkan sejak dari proses rekrutmen pegawai, penilaian kinerja, remunerasi, hingga pengembangan kompetensi dan jenjang karir. Jumlah pegawai PLN dan anak perusahaan sebesar 54.124 orang terdiri dari 37.335 pegawai laki-laki (82\%) dan 8.272 pegawai perempuan (18\%). Bidang pekerjaan PLN yang menuntut harus siap bekerja di lapangan tanpa mengnal waktu membuat komposisi pegawai laki-laki yang lebih banyak daripada pegawai perempuan. Namun kebijakan non-diskriminasi dan kesetaraan gender tetap merupakan bagian dari kebijakan perusahaan.

Program Pengembangan Kepemimpinan PLN menciptakan kader pimpinan baru, dilakukan dengan Program Executive Education, terdiri dari: Executive Education I untuk level manajemen atas, Executice Education II untuk level manajemen menengah, dan Executive Education III untuk level manajemen dasar.

\section{Penghargaan}

Tantangan berat yang dihadapi tidak menyurutkan etos kerja insan PLN untuk memberikan yang terbaik. PLN berupaya keras mengatasi seluruh tantangan yang menghadang dalam merealisasikan target pembangunan infrastruktur kelistrikan hingga ke pelosok negeri. Banyak prestasi nyata yang dicapai perusahaan.

1) Kemudahan Mendapatkan Listrik

Available Online: $\underline{\text { https://dinastirev.org/JMPIS }}$

Page 203 
Dari hasil survei readiness, nurturing leadership, leader exposure, dan leader (EoDB) Bank Dunia tentang "Kemudahan Mendapatkan Listrik", Indonesia berada di peringkat 33 dari 190 negara yang disurvei, naik dibandingkan survei sebelumnya di peringkat 38. Aspek penilaian kemudahan mendapatkan listrik menjadi salah satu parameter pendukung pemeringkatan "Kemudahan Berinvestasi" atau readiness, nurturing leadership, leader exposure, dan leader (EoDB) oleh Bank Dunia dimana Indonesia berhasil menempati 73 dalam kemudahan berbisnis di antara 190 negara dunia dan peringkat 9 di antara negara Asia Timur dan Pasifik. Hal ini membuktikan kontribusi positif PLN terhadap upaya Pemerintah mendorong peningkatan investasi di Indonesia.

2) Rasio Elektrifikasi

Target PLN atas rasio elektrifikasi adalah 93\% dari target rasio elektrifikasi Nasional. PLN telah berhasil melampaui target tersebut dengan mencapai rasio elektrifikasi sebesar 97,05\% . Melalui program 3T yaitu Tertinggal, Terpencil dan Terdepan, hingga akhir tahun PLN berhasil melistriki 3.359 desa, sehingga jumlah desa teraliri listrik di seluruh wilayah Indonesia adalah 79.041 desa atau 95,95\%. Melalui program sponsorship sinergi BUMN yang melibatkan 34 BUMN, masyarakat miskin dapat menikmati sambungan listrik gratis.

3) Pengelolaan lingkungan

Program program lingkungan di PLN berfokus untuk mewujudkan zero waste material untuk mendukung upaya Pemerintah mencapai tujuan pembangunan berkelanjutan (Sustainable Development Goals. Pada tahun 2019, 3 unit PLN berhasil meraih PROPER Emas yaitu PLTU Tanjung Jati B, PLTU Paiton yang dikelola oleh PT Pembangkitan Jawa Bali (PT PJB) dan PLTDG Pesanggaran yang dikelola oleh PT Indonesia Power. PROPER Emas merupakan penghargaan pengelolaan lingkungan yang tertinggi dan diberikan kepada perusahaan yang mampu mengelola aspek efisiensi pemanfaatan sumber daya alam dan peningkatan keanekaragaman hayati, serta praktik pemberdayaan masyarakat melalui program CSR. Selain PROPER Emas, terjadi peningkatan peringkat PROPER Pembangkit PLN dan anak perusahaan yaitu peringkat Hijau (dari 15 menjadi 16) dan Biru (dari 81 menjadi 82).

\section{Transaksi dengan pihak-pihak yag berelasi (Afiliasi)}

Dalam kegiatan usahanya, transaksi yang dilakukan oleh perusahaan dengan pihakpihak yang mempunyai hubungan istimewa atau berelasi telah memenuhi persyaratan akuntansi sesuai ketentuan dalam Pernyataan Standar Akuntansi Keuangan (PSAK) yaitu berupa pengungkapan didalam catatan atas laporan keuangan konsolidasi.

Sifat Hubungan Berelasi

1) Pemerintah Republik Indonesia merupakan pemegang saham Perusahaan dan Badan Usaha Milik Negara.

2) Perusahaan dan entitas anak mempunyai pengaruh signifikan atas investasi pada entitas asosiasi.

3) Pengurus Koperasi Karyawan juga merupakan pegawai Perusahaan dan entitas anak.

4) Pendiri dan pengawas Yayasan Pendidikan dan Kesejahteraan PT PLN (Persero) merupakan pengurus dan karyawan Perusahaan dan entitas anak.

5) Yayasan Pendidikan dan Kesejahteraan PT PLN (Persero) merupakan pemegang saham mayoritas PT Tugu Kresna Pratama.

6) Dewan Komisaris dan Direksi merupakan personil manajemen kunci Perusahaan dan entitas anak. Ketentuan Transaksi Berelasi. 
Dalam melakukan transaksi dengan pihak-pihak yang berelasi tersebut, PLN menerapkan kebijakan sebagai berikut:

a. Penjualan produk dan jasa kepada pihak berelasi ditetapkan berdasarkan kontrakkontrak penjualan, yang pada umumnya menggunakan dasar harga pasar yang berlaku ditambah margin tertentu sesuai kesepakatan.

b. Pengangkutan bahan bakar maupun suku cadang oleh pihak berelasi ditetapkan berdasarkan kontrak pengangkutan yang disepakati bersama berdasarkan hasil negosiasi dengan memperhatikan unsur-unsur biaya yang ada ditambah dengan marjin tertentu.

c. Penempatan dana dilakukan berdasarkan kebutuhan dan perjanjian yang saling menguntungkan dan memberikan benefit optimal pada Perseroan.

d. Perolehan dana pinjaman dilakukan melalui negosiasi syarat dan kondisi yang paling optimal bagi kepentingan operasional Perseroan.

\section{Standar Etika Perusahaan atau Pedoman Perilaku/Code of Conduct (CoC)}

Pada tahun 2005, Perusahaan mengeluarkan Standar Etika Perusahaan atau Pedoman Perilaku/Code of Conduct (CoC) sebagai panduan bagi seluruh insan PLN untuk senantiasa berperilaku profesional dan menjunjung tinggi integritas di lingkungan kerjanya. Pedoman Perilaku mengatur aspek kepemimpinan di Perusahaan, keanggotaan yang bertanggung jawab, hubungan profesional antar anggota dan hubungan dengan pihak eksternal. Selain itu, Pedoman Perilaku merupakan sarana untuk menciptakan hubungan yang harmonis, sinergis dan saling menguntungkan di antara seluruh pemangku kepentingan Perusahaan.

Pada tahun 2010, melalui Keputusan Direksi Nomor: 548A/K/DIR/2010 tentang Buku Pedoman Perilaku, Perusahaan memperbarui butir-butir ketentuan dalam Pedoman Perilaku, untuk menyesuaikan dengan Pedoman GCG dan praktik bisnis yang telah berkembang semakin kompleks. Pedoman Perilaku dibuat dalam bentuk buku saku yang ringkas agar mudah dibawa saat beraktivitas. Melalui berbagai bentuk sosialisasi dan internalisasi, Perusahaan mendorong komitmen kepatuhan seluruh insan PLN terhadap standar etika dan mewajibkan seluruh pimpinan untuk memastikan bahwa Pedoman Perilaku dipatuhi dan dijalankan dengan baik di jajarannya masing-masing. Di akhir tahun 2018, dilakukan pembaruan terhadap Pedoman Perilaku dan Etika Bisnis Perusahaan yang akan segera dilakukan diseminasi kepada seluruh pegawai. Objek Standar Etika Perusahaan Standar Etika Perusahaan wajib dipatuhi dan dilaksanakan oleh:

1) Seluruh insan PLN di segala tingkatan termasuk Dewan Komisaris, Direksi dan organ pendukung Dewan Komisaris;

2) Direksi, Dewan Komisaris serta pegawai anak perusahaan dan afiliasi di bawah pengendalian; 3. Investor PLN (kreditur, pemegang obligasi, dan lain-lain);

3) Para pemangku kepentingan PLN seperti pelanggan, mitra kerja/pemasok, pesaing, investor, Pemerintah/DPR, masyarakat, media, organisasi, profesi/instiusi pendidikan, penegak hukum.

Penandatanganan Komitmen Standar Etika Perusahaan Seluruh insan PLN wajib menandatangani komitmen mematuhi Standar Etika Perusahaan. Penandatanganan komitmen dilakukan setiap tahun secara online melalui portal internal PLN sehingga lebih efisien waktu dan biaya serta lebih mudah untuk didokumentasikan. Pada tahun 2019, persentase penandatanganaan komitmen Standar Etika Perusahaan mencapai 85\% dari seluruh pegawai Perusahaan. Pokok-Pokok Standar Etika Perusahaan Standar Etika 
Perusahaan mengatur sejumlah aspek penting seperti kepemimpinan PLN, keanggotaan yang bertanggung jawab, hubungan profesional antar anggota, dan hubungan dengan pihak eksternal.

Perusahaan terus melakukan sosialisasi Standar Etika Perusahaan untuk memberikan pemahaman dan menumbuhkan kesadaran seluruh insan PLN agar senantiasa menegakkan Standar Etika Perusahaan. Sepanjang tahun 2019, sosialisasi dilakukan baik secara langsung ke unit bisnis maupun melalui situs web PLN yang dikenal dengan website KOMANDO (budaya.pln.co.id). Setiap Divisi atau Unit bisnis diberi target pencapaian Standar Etika Perusahaan yang menjadi bagian dalam Key Performance Indicator (KPI). Pemantauan atas pencapaian target tersebut dilakukan dalam sharing session rutin setiap minggu.

Sanksi Pelanggaran Standar Etika Perusahaan Perusahaan menetapkan sanksi bagi pelanggaran Standar Etika Perusahaan sebagai berikut:

a. Mitra kerja PLN: sanksi sesuai dengan peraturan dan keputusan Perusahaan

b. Insan PLN: tindakan-tindakan disipliner berupa teguran lisan maupun tulisan, peringatan keras dengan skorsing sampai pemutusan hubungan kerja;

c. Apabila mengakibatkan pelanggaran hukum, pemasalahan dapat diproses lebih lanjut kepada pihak yang berwajib. Selama tahun 2019, sanksi atas pelanggaran telah diberikan dengan mengacu pada ketentuan internal Perusahaan dan Perjanjian Kerja Bersama (PKB).

\section{Whistleblowing System}

Perusahaan telah mengimplementasikan sistem pelaporan pelanggaran atau whistleblowing system ("WBS") sebagai salah satu cara yang dinilai paling efektif untuk mencegah dan memerangi praktik korupsi, suap, dan praktik-praktik kecurangan lainnya yang bertentangan dengan kaidah GCG. Pedoman Whistleblowing System Sejak tahun 2012, PLN bekerja sama dengan lembaga yang kompeten untuk membuat kajian dan merancang sistem pelaporan pelanggaran yang sesuai dengan kondisi dan budaya perusahaan, untuk diterapkan di seluruh jajaran bisnis Perseroan, baik di unit bisnis maupun di anak usaha.

Pada tanggal 20 Desember 2012, Perusahaan secara resmi memberlakukan sistem pelaporan pelanggaran (whistleblowing system) di seluruh jajaran bisnis PLN melalui Surat Edaran Direksi Nomor: 21.E/ Dir/2012 tentang Sistem Pelaporan Pelanggaran (Whistleblowing System). Surat Edaran Direksi tersebut juga mengatur mekanisme pelaporan, perlindungan pelapor dan tindak lanjut.

Pengelola WBS Penanggung jawab pelaksanaan mekanisme WBS adalah Satuan Pengawasan Intern (SPI) melalui penetapan Surat Edaran Direksi Nomor: 008.E/ DIR/2016 Tanggal 30 September 2016 tentang Sistem Pelaporan.

Setelah menerima laporan pengaduan, Direktur Utama akan meneruskan laporan pengaduan tersebut kepada Chief Audit Executive (CAE) untuk melakukan investigasi di lapangan melalui Tim Investigasi Audit Khusus. Petugas database WBS akan mendokumentasikan laporan pengaduan tersebut dan hasil investigasinya.

Hasil investigasi Tim Investigasi dilaporkan kepada CAE yang selanjutnya melaporkan kepada Direktur Utama dan Executive Vice President Human Capital Management System (EVP HCMS). Jika hasil investigasi membuktikan adanya pelanggaran oleh pegawai/pejabat yang dilaporkan, maka yang bersangkutan akan dikenakan sanksi atau Tuntutan Ganti Rugi (TGR) sesuai ketentuan Perusahaan. 
Perlindungan Terhadap Pelapor Perusahaan dalam hal ini SPI sebagai penanggung jawab WBS memberikan jaminan perlindungan bagi pelapor pelanggaran sebagai berikut:

1) Melindungi kerahasiaan identitas pelapor (nama, alamat, nomor telepon, faksimili, email, unit kerja, dan lain-lain). Komunikasi dengan pelapor dilakukan menggunakan media komunikasi email di luar pengeloaan perusahaan (bukan alamat email pln.co.id);

2) Melindungi kerahasiaan identitas pelapor (nama, alamat, nomor telepon, faksimili, email, unit kerja, dan lain-lain). Komunikasi dengan pelapor dilakukan menggunakan media komunikasi email di luar pengeloaan perusahaan (bukan alamat email pln.co.id);

3) Perlindungan atas tindakan balasan dari terlapor/lembaga pelapor;

4) Perlindungan dari tindakan internal PLN: a. Tekanan; b. Penundaan kenaikan pangkat/jabatan; c. Pemecatan; d. Gugatan hukum; e. Harta benda hingga tindakan fisik; f. Perlindungan yang diberikan tidak hanya berlaku bagi pelapor tetapi dapat diperluas kepada anggota keluarga pelapor.

\section{Pencegahan transaksi orang dalam}

Perusahaan memiliki kebijakan mengenai transaksi keuangan Perusahaan yang diatur dalam Peraturan Direksi Nomor: 0054.K/DIR/2014 tentang Pedoman Transaksi Keuangan Antara PT PLN (Persero) dengan Mitra Kerja Guna Mendukung PLN Bersih. Tujuan kebijakan ini adalah untuk menghindarkan insan PLN dari segala bentuk penyimpangan praktik bisnis termasuk korupsi, kolusi, dan nepotisme.

Untuk mencegah kecurangan transaksi, setiap transaksi antara PLN dengan mitra kerja seperti perjanjian/kontrak pembangunan fasilitas kelistrikan dan perjanjian/kontrak penyediaan barang/jasa, dilakukan melalui transaksi non-cash (melalui jasa perbankan).

PLN telah berkomitmen untuk mewujudkan pengelolaan Perusahaan yang bersih, sehat, dan bebas dari segala bentuk Korupsi, Kolusi, dan Nepotisme (KKN). Salah satu perangkat untuk mendukung komitmen tersebut adalah kebijakan mengenai gratifikasi dan benturan kepentingan yang diatur dalam Peraturan Direksi Nomor: 0076.P/DIR/ 2017 tentang Pedoman Pengendalian Gratifikasi di PLN yang merupakan turunan dari Peraturan Direksi Nomor: 0060.K/DIR/2014 tentang Pedoman PLN Bersih.

Pedoman tersebut mengatur secara jelas beragam penafsiran mengenai gratifikasi di lingkungan Perusahaan yang bertujuan untuk memperkuat posisi Perusahaan dalam menghadapi persaingan usaha, meningkatkan efisiensi dan efektivitas pengelolaan sumber daya, memaksimalkan nilai Perusahaan secara berkelanjutan serta meningkatkan kepercayaan pemangku kepentingan.

Pengawasan Gratifikasi Setiap bentuk gratifikasi yang diterima maupun ditolak, wajib disampaikan dan dilaporkan kepada Unit Pengendali Gratifikasi yang ditetapkan oleh Direksi PLN. Pelanggaran akan dikenakan sanksi sesuai dengan peraturan perundangundangan dan peraturan Perusahaan yang berlaku. Etika Gratifikasi dalam menjalankan kegiatannya, setiap insan PLN wajib menjunjung tinggi komitmen untuk menjalankan usaha yang bebas dengan segala bentuk kecurangan (fraud) dan tindakan korupsi dengan mematuhi ketentuan-ketentuan sebagai berikut:

1) Semua insan PLN dilarang menawarkan atau memberikan suap dan gratifikasi dalam bentuk apapun. 
2) Semua insan PLN dilarang meminta atau menerima gratifikasi, baik secara langsung maupun tidak langsung, dari pemangku kepentingan, mitra kerja dan/atau pihak ketiga karena jabatannya, dan berlawanan dengan kewajiban atau tugasnya.

3) Semua insan PLN wajib berpartisipasi untuk menyukseskan program pencegahan korupsi di lingkungan Perusahaan.

4) Semua insan PLN wajib melakukan penolakan secara sopan terhadap segala bentuk pemberian yang tidak sesuai dengan ketentuan pedoman gratifikasi.

5) Semua insan PLN harus melaporkan kepada Unit Pengendali Gratifikasi atas penerimaan, permintaan, dan/atau penolakan gratifikasi yang dilakukan. Pelaporan Gratifikasi Perusahaan membuka saluran untuk melaporkan gratifikasi dalam bentuk aplikasi Compliance Online System yang dapat diakses oleh seluruh pegawai PLN melalui http://cos.pln.co.id.

\section{Komitmen dan Kebijakan Lingkungan}

Salah satu misi Perusahaan adalah "Menjalankan kegiatan usaha yang berwawasan lingkungan". Sejalan dengan misi tersebut, PLN selalu berusaha memperhatikan aspek lingkungan dalam menjalankan setiap kegiatannya. PLN berkomitmen untuk menjalankan aktivitas usaha yang berwawasan lingkungan dan sadar sepenuhnya bahwa bisnis pembangkitan tenaga listrik memiliki dampak langsung terhadap lingkungan sekitarnya. Oleh karena itu, untuk melindungi ekosistem bumi beserta seluruh isinya bagi kepentingan kehidupan generasi mendatang, PLN melakukan upaya-upaya yang terukur untuk mengendalikan pencemaran tanah, air dan udara oleh zat-zat polutan termasuk pengurangan emisi gas rumah kaca secara menyeluruh dalam semua kegiatan penyediaan listrik baik pada instalasi pembangkit, transmisi/gardu induk dan distribusi, serta aktivitas operasional anak perusahaan.

Untuk mendukung upaya tersebut, PLN telah menetapkan aspek lingkungan sebagai salah satu unsur penilaian dalam kinerja unit bisnis PLN di seluruh Indonesia. Melalui penilaian kinerja ini, Perusahaan dapat terus-menerus mengevaluasi pemenuhan komitmennya di bidang lingkungan. Dampak dan Risiko Lingkungan Penting yang Terkait Secara Langsung atau Tidak Langsung Dengan Perusahaan Proses pembangkitan listrik pada instalasi pembangkit dan jaringan transmisi menghasilkan beberapa limbah spesifik, yakni:

1) Emisi gas rumah kaca (GRK),

2) Limbah cair, berupa air dari pembangkit PLTU,

3) Limbah cair berupa pelumas bekas yang termasuk bahan berbahaya dan beracun (B3),

4) Limbah padat seperti abu batu bara, insulator keramik, kabel bekas, aki bekas kendaraan operasional dan tiang-tiang listrik.

Program-program lingkungan di PLN berfokus untuk mewujudkan zero waste material dan menumbuhkan citra positif Perusahaan di persepsi seluruh pemangku kepentingan. Untuk mendukung upaya Pemerintah mencapai tujuan pembangunan berkelanjutan (Sustainable Development Goals/ SDGs), khususnya di bidang reduksi emisi, Perseroan telah menyusun 8 program utama di bidang lingkungan, yaitu:

a. Pengawasan penyelesaian Dokumen Lingkungan sesuai dengan RUPTL 2017-2026 dan RKAP 2017 sebanyak 8 proyek;

b. Pemenuhan PROPER (Program Penilaian Peringkat Kinerja Perusahaan dalam Pengelolaan Lingkungan Hidup) Pembangkit minimal peringkat Biru di PLN dan anak perusahaan; 
c. Pengawasan kesesuaian kelengkapan Dokumen Lingkungan, Izin Lingkungan, dan Izin Perlindungan dan Pengelolaan Lingkungan Hidup (PPLH);

d. Sertifikasi Sistem Manajemen Lingkungan (SML) ISO 14001 bagi unit-unit yang belum tersertifikasi SML ISO 14001;

e. Program penghijauan;

f. Capacity building (HSSE Academy);

g. Sistem visual manajemen lingkungan;

h. Implementasi Project Management Office (PMO).

\section{Tanggungjawab terhadap pelanggan}

Dalam memberikan pelayanan kepada pelanggan, PLN menggunakan pendekatan yang berbeda pada setiap kelompok pelanggan. Kelompok pelanggan rumah tangga, bisnis dan industri akan memiliki karakteristik kebutuhan spesifik masing-masing. Oleh karenanya, dengan program pemasaran yang berorientasi pelanggan, PLN semakin proaktif dan berupaya memahami rencana pelanggan atau calon pelanggan, untuk membantu membuat rencana bisnis yang selaras dengan kebutuhan pelanggan.

Untuk kelompok pelanggan rumah tangga, PLN menyiapkan berbagai program layanan sesuai dengan kebutuhan, seperti listrik pintar, akses pengaduan melalui layanan Call Center 123, PLN Mobile, dan sebagainya.

Untuk kelompok pelanggan industri dan bisnis, PLN merancang program-program khusus untuk mengetahui, mengerti dan berusaha memenuhi kebutuhan spesifik mereka, seperti layanan premium untuk memberikan pasokan listrik yang andal, account officer untuk menyediakan kemudahan mendapatkan pelayanan listrik, akses informasi perbaikan jaringan listrik, akses keluhan pelanggan, kemudahan pembayaran tagihan dan sebagainya.

Kegiatan/Program yang Dilakukan dan Dampaknya Tanggung jawab PLN kepada konsumen ditujukkan dengan melaksanakan program-program perbaikan kualitas yang berkelanjutan baik dari sisi operasional maupun pengembangan usaha. Perbaikan berkelanjutan terutama bertujuan untuk memperbaiki persepsi pelanggan terhadap kualitas layanan PLN dalam menyediakan kebutuhan listrik. Sejalan dengan tuntuan efisiensi operasional dan meminimalkan human error, PLN semakin intensif mengembangkan sistem layanan berbasiskan sistem teknologi informasi.

Program-program yang telah dilaksanakan untuk meningkatkan kualitas layanan kepada konsumen meliputi:

1) Penyediaan account officer dan official account untuk pelanggan-pelanggan utama maupun pelanggan bisnis dan komersial utama.

2) Pengembangan sistem penagihan dan penyambungan, yakni Aplikasi Pelayanan Pelanggan Terpadu (AP2T) dan Pengelolaan dan Pengawasan Arus Pendapatan Secara Terpusat (P2APST).

3) Pengembangan pelayanan borderless, yang meliputi:

\section{KESIMPULAN DAN SARAN}

1. Etika bisnis dalam perusahaan memiliki peran yang sangat penting, yaitu untuk membentuk suatu perusahaan yang kokoh dan memiliki daya saing yang tinggi serta mempunyai kemampuan menciptakan nilai (value-creation) yang tinggi. 
2. PLN telah memiliki Standar Etika Perusahaan atau Pedoman Perilaku/Code of Conduct (CoC) sebagai panduan bagi seluruh insan PLN untuk senantiasa berperilaku profesional dan menjunjung tinggi integritas di lingkungan kerjanya. Pedoman Perilaku mengatur aspek kepemimpinan di Perusahaan, keanggotaan yang bertanggung jawab, hubungan profesional antar anggota dan hubungan dengan pihak eksternal.

3. Tata Nilai PLN merupakan panduan bagi seluruh Insan PLN, dalam pola pikir, sikap, dan perilaku sehari-hari dalam bekerja untuk memberikan kontribusi kepada Perusahaan yang dirumuskan dalam belief, values, dan behavior yang harus tercermin dalam 3P yaitu Perbuatan, Pikiran dan Prinsip.

4. Agar Pedoman Perilaku PLN dapat terus menjadi pedoman seluruh Insan PLN, sosialisasi perlu terus digiatkan ke seluruh pegawai PLN sehingga menjadi budaya yang melekat dan menjadi norma kebiasaan dalam pekerjaan sehari-hari.

\section{DAFTAR RUJUKAN}

- Ali, Hapzi. 2020. Modul Business Ethic \& GG. Universitas Mercu Buana. Jakarta.

- Mulyaningsih., Hermina, Tinneke.(2017). Etika Bisnis, CV KIMFA MANDIRI, ISBN: $978-602-50828-0-1$

- Keraf, Sonny. 1998, Etika Bisnis (Tuntutan dan Relevansinya), Yogyakarta: Kanisius.

- Floyd,Larry A., Feng,Xu.,Atkins,Ryan.,Caldwell,Cam.(2013).Ethical Outcomes and Business Ethics: Towards Improving Business Ethics Education. Journal Business Ethics (2013) 117:753-776

- Wagner, Sigmund., Tsukamoto.2008.Contrasting the Behavioural Business Ethics Approach and the Institutional Economic Approach to Business Ethics: Insights From the Study of Quaker Employers. Journal of business Ethics:Dordrecht Vol 82, Iss 4 (November 2008)

- Annual Report PLN. 2019,. https://www.pln.co.id/statics/uploads/2019/11/PLN-AR2018_Final-Upload-Website-1.pdf.( 3 April 2020, jam 20.00 WIB)

- Widodo, D.S., Silitonga,P.E.S., Ali,H.2017. Analysis of Organizational Performance Predictors of Transformational Leadership Style, Services Leadership Styles and Organizational Learning (Studies in Jakarta Government), International Journal of Economic Research 